\title{
Evaluation of DNase activity in seminal plasma and uptake of exogenous DNA by spermatozoa of the Brazilian flounder Paralichthys orbignyanus
}

\author{
C.F.C. Lanes ${ }^{a}$, L.A. Sampaio ${ }^{b}$, L.F. Marins ${ }^{a}{ }^{\text {,* }}$ \\ ${ }^{a}$ Departamento de Ciências Fisiológicas, Universidade Federal do Rio Grande, CP 474, 96201-900, Rio Grande, RS, Brazil \\ ${ }^{\mathrm{b}}$ Departamento de Oceanografia, Universidade Federal do Rio Grande, CP 474, 96201-900, Rio Grande, RS, Brazil
}

Received 30 November 2007; received in revised form 9 July 2008; accepted 14 August 2008

\begin{abstract}
Sperm mediated gene transfer (SMGT) has been successfully used in mammals, amphibians, birds, and some invertebrates. In fish, this methodology has failed or had poor efficiency for the production of transgenic specimens, presumably because the processes regulating the interaction between spermatozoa and exogenous DNA are not well understood. Therefore, the objective was to develop a SMGT protocol for the Brazilian flounder Paralichthys orbignyanus, with an emphasis on the role of seminal plasma DNase on exogenous DNA uptake by fish spermatozoa. In this study, there was strong DNase activity in the seminal plasma of $P$. orbignyanus; however, this DNase activity was decreased or eliminated by washing the spermatozoa with solutions containing EDTA (DNase activity was completely inhibited by $40 \mathrm{mM}$ EDTA). Three washing solutions were tested, all of which maintained sperm quality. Moreover, it was determined that the no more than $50 \mathrm{ng}$ of exogenous DNA $/ 10^{6}$ cells should be used for SMGT in fish. Finally, it was demonstrated that fish spermatozoa were capable of spontaneous uptake of exogenous DNA after elimination of DNase activity; this was confirmed by exogenous DNA amplification (PCR using sperm genomic DNA as a template) after DNase I treatment. We concluded that whereas DNase activity was an important obstacle for exogenous DNA uptake by fish spermatozoa; controlling this activity improved the efficiency of SMGT in fish.
\end{abstract}

(C) 2009 Published by Elsevier Inc.

Keywords: DNase; Spermatozoa; DNA uptake; SMGT; Paralichthys orbignyanus

\section{Introduction}

Several techniques are currently available for transgenic fish production, including: microinjection of DNA into pronuclei/nuclei of fertilized eggs [1], egg and semen electroporation [2,3], gonad lipofection [3], retroviral vectors [4], and particle gun bombardment [5]. Among

\footnotetext{
* Corresponding author at: Universidade Federal do Rio Grande, Departamento de Ciências Fisiológicas, Av. Itália, Km 8, CEP $96201-$ 900, Rio Grande, RS, Brazil. Tel.: +55 5332336851.

E-mail address: dqmluf@furg.br (L.F. Marins).
}

them, microinjection has been more extensively used and has achieved a higher degree of success for producing transgenic fish. However, besides being laborious, its success is limited by characteristics of eggs from some species (small size, hard chorion, fragility, opacity, etc.) [6]. Highly efficient gene transfer techniques for most marine fish have not yet been established. Sperm mediated gene transfer (SMGT) could be useful to achieve transgenesis in species with high fecundity, small eggs, and easy access to spermatozoa, such as the Brazilian flounder Paralichthys orbignyanus.

Sperm mediated gene transfer has been successfully applied in mammals [7-9], birds [10], amphibians [11], 
and some invertebrates $[12,13]$. Good SMGT results for fish were obtained only when semen was electroporated, as demonstrated for tilapia Oreochromis niloticus [14], zebrafish Danio rerio [15], salmon Oncorhynchus tshawytscha [16], grass carp Ctenopharyngodon idellus [17], and silver sea bream Sparus sarba [3]. However, if semen was incubated with exogenous DNA but not electroporated, the efficiency of SMGT for transgenic fish production was low or nonexistent [1720]. The only exception was that Khoo et al. [21] reported high rates of transgenic zebrafish production by incubating spermatozoa directly with exogenous DNA.

That SMGT has failed or had poor efficiency for the production of transgenic fish was attributed to a lack of understanding regarding processes regulating the interaction between spermatozoa and exogenous DNA. Conversely, in mammals, it is already known that $30-35 \mathrm{kDa}$ proteins positively interact with exogenous DNA, allowing its internalization by the sperm nucleus [22]. However, molecules such as inhibitory factor 1 (IF-1) and DNase, which are generally found in the seminal plasma of mammals, also act as negative regulators of this interaction [22,23]. Furthermore, other factors, such as semen quality, semen origin (ejaculated or epididymal), time and temperature of semen incubation with DNA, amount of exogenous DNA per sperm cell, and DNA architecture, also affected the uptake of exogenous DNA by spermatozoa $[9,24,25]$. Therefore, the aim of this study was to develop a SMGT protocol for the Brazilian flounder P. orbignyanus by evaluating the role of seminal plasma DNase on exogenous DNA uptake by fish spermatozoa.

\section{Materials and methods}

\subsection{Fish and sperm collection}

Adult Brazilian flounders were captured during breeding season (October-April) at Cassino Beach (Southern Brazil, $32^{\circ} 12^{\prime} \mathrm{S}-52^{\circ} 10^{\prime} \mathrm{W}$ ), and taken to the Laboratory of Mariculture at the Federal University of Rio Grande (FURG). Mature males $(479 \pm 83 \mathrm{~g} ; 34 \pm 2 \mathrm{~cm}$, mean $\pm \mathrm{SEM})$ were identified by the presence of running milt. They were kept in the laboratory in $1000 \mathrm{~L}$ tanks for no longer than $3 \mathrm{~d}$ before semen collection. Water was exchanged at least $100 \%$ daily, its temperature was maintained at $25 \pm 2{ }^{\circ} \mathrm{C}$, salinity was $35 \%$, and photoperiod of $14 \mathrm{~h}$ of light/d was provided by incandescent bulbs.
Unless otherwise mentioned, spermatozoa and seminal plasma used throughout this study were obtained from ejaculated semen. Before semen was collected, fish were anesthetized with $50 \mathrm{ppm}$ benzocaine (Sigma Chemical Co., St. Louis, MO, USA) in a plastic tank $(50 \mathrm{~L})$. To minimize contamination by urine or feces, fish bladders were cleared by abdominal pressure and the urogenital areas were blotted dry with paper towel. Semen was obtained by gentle abdominal massage, collected in 1-mL syringes (without a needle), and immediately transferred to $1.5-\mathrm{mL}$ microtubes.

\subsection{DNA substrate}

A circular DNA plasmid (pKeratin-GFP) was used in this study (kindly provided by Dr. Takashi Aoki, Tokyo University of Marine Science and Technology, Japan). It contained the keratin promoter of hirame Paralichthys olivaceus associated with the green fluorescent protein (GFP) gene of jellyfish Aequorea victoria [5]. The GFP gene was used as PCR target for identification of transgenic sperm.

\subsection{Experiment 1: Detection of DNase activity in seminal plasma}

Seminal plasma from three sources was used to evaluate DNase activity: ejaculated semen, semen collected from the lumen of the testes, and semen from macerated testes $(n=3)$. Ejaculated semen was collected as described above. Testes were dissected from flounder immediately after their death, washed on a petri dish with distilled water, and dried with paper towel. Semen from the lumen was collected with plastic syringes and transferred to $1.5 \mathrm{~mL}$ microtubes. Intact testes were macerated with a teflon pestel in $1.5 \mathrm{~mL}$ microtubes (without using any diluents).

Semen from all sources was centrifuged at $12,000 \times g$ for $20 \mathrm{~min}$ immediately after collection. Seminal plasma was removed and stored at $-20{ }^{\circ} \mathrm{C}$ until use. An aliquot $(1 \mu \mathrm{L})$ pKeratin-GFP $(350 \mathrm{ng} / \mu \mathrm{L})$ and $8 \mu \mathrm{L}$ of seminal plasma were mixed and incubated at $20{ }^{\circ} \mathrm{C}$ for $50 \mathrm{~min}$; this temperature was used since it yielded better results in obtaining natural spawning in captivity [26]. Subsequently, DNA was analyzed by electrophoresis on $1 \%$ agarose gel containing ethidium bromide $(0.5 \mu \mathrm{g} / \mathrm{mL})$ and visualized under a UV light. Degradation of pKeratin-GFP was quantified by fluorescence analysis using a Qubit fluorometer and Quant-iT dsDNA BR kit (Invitrogen, Carlsbad, CA, USA), following the protocol recommended by the manufacturer. 


\subsection{Experiment 2: Determination of optimum incubation time and temperature of DNase activity}

Seminal plasma samples from three fish were pooled in these experiments. Evaluation of optimum incubation time and temperature was carried out incubating a mixture of $1 \mu \mathrm{L}$ pKeratin-GFP $(350 \mathrm{ng} / \mu \mathrm{L})$ and $8 \mu \mathrm{L}$ seminal plasma for $0,15,30,45,60,90$, and $120 \mathrm{~min}$ at $20{ }^{\circ} \mathrm{C}$ (incubation time experiment); or a mixture of $1 \mu \mathrm{L}$ pKeratin-GFP (350 ng/ $\mu \mathrm{L}), 4 \mu \mathrm{L}$ seminal plasma, and $4 \mu \mathrm{L}$ distilled water at $8,16,24,32,40,48,56$, and $64{ }^{\circ} \mathrm{C}$ for $30 \mathrm{~min}$ (temperature experiment). At $0 \mathrm{~min}$, the transgene was added at the exact moment electrophoresis started. Thereafter, reactions were analyzed by electrophoresis and fluorescence, as previously described.

\subsection{Experiment 3: Determination of DNase concentration in seminal plasma}

Various concentrations of seminal plasma were incubated with pKeratin-GFP in order to obtain a concentration curve for determination of the amount of endogenous DNase in seminal plasma. Seminal plasma was diluted 1:1, 1:5, 1:10 and 1:20 (v/v) with distilled water. For each reaction, $1 \mu \mathrm{L}$ pKeratin-GFP $(350 \mathrm{ng} / \mu \mathrm{L})$ and $1 \mu \mathrm{L}$ of each dilution was used. Three other reactions were composed of 1,5 , and $10 \mu \mathrm{L}$ of undiluted seminal plasma, and mixed with $1 \mu \mathrm{L}$ pKeratin-GFP $(350 \mathrm{ng} / \mu \mathrm{L})$. Reactions were incubated for $15 \mathrm{~min}$ at $32{ }^{\circ} \mathrm{C}$.

A concentration curve for commercial DNase I (Epicentre, Madison, WI, USA) was made using $1 \mu \mathrm{L}$ of pKeratin-GFP plasmid $(350 \mathrm{ng} / \mu \mathrm{L})$ and $1 \mu \mathrm{L}$ of commercial DNase $(1,0.1,0.05,0.03,0.025,0.02$, $0.01 \mathrm{U} / \mu \mathrm{L})$. According to the manufacturer, 1 unit $(\mathrm{U})$ of DNase I completely digests $1 \mu \mathrm{g}$ of DNA to oligonucleotides in $10 \mathrm{~min}$ at $37^{\circ} \mathrm{C}$. Thus, reactions were incubated for $15 \mathrm{~min}$ at $37^{\circ} \mathrm{C}$.

Thereafter, reactions were analyzed by electrophoresis and fluorescence, as previously described. The results obtained for commercial DNase activity were used to perform a linear regression analysis between the amount of DNase used and remaining exogenous DNA, in order to calculate the concentration of endogenous DNase in the seminal plasma of Brazilian flounder.

\subsection{Experiment 4: Evaluation of EDTA on DNase activity}

To evaluate the inhibiting role of EDTA on DNase activity, various concentrations of EDTA (Sigma, St. Louis, MO, USA) were tested. An aliquot of $3 \mu \mathrm{L}$ of seminal plasma (pooled from three fish), $1 \mu \mathrm{L}$
pKeratin-GFP (350 ng/ $\mu \mathrm{L})$, and $3 \mu \mathrm{L}$ EDTA (5, 25, $50,75,100,250$, and $500 \mathrm{mM}$ EDTA) were mixed and incubated at room temperature $\left(20{ }^{\circ} \mathrm{C}\right)$ for $50 \mathrm{~min}$. The final EDTA concentration in each reaction was 2, 10, $20,30,40,105$, and $215 \mathrm{mM}$, respectively. Thereafter, reactions were analyzed by electrophoresis and fluorescence, as previously described.

\subsection{Experiment 5: Evaluation of optimum concentration of exogenous DNA to use in SMGT}

The sperm concentration in semen $(50 \mu \mathrm{L})$ fixed in $4 \%$ formalin and diluted in distilled water (1:2000) was determined using an improved Neubauer Bright line counting chamber (Laboroptik, Friedrichsdorf, Germany) under a microscope at $400 \times$ magnification (Olympus CX-41, Miami, FL, USA). Original semen samples $(n=3)$ were diluted with $50 \mathrm{mM}$ EDTA for a final concentration of $10^{6}$ cells $/ \mu \mathrm{L}$, and used to verify toxicity of exogenous DNA. An aliquot $(5 \mu \mathrm{L})$ of pKeratin-GFP $(50,100$, and $500 \mathrm{ng} / \mu \mathrm{L})$ was incubated with $5 \mu \mathrm{L}$ semen $\left(10^{6}\right.$ spermatozoa/ $\left.\mu \mathrm{L}\right)$ for $50 \mathrm{~min}$ at room temperature $\left(20^{\circ} \mathrm{C}\right)$. Samples containing only $5 \mu \mathrm{L}$ semen were also maintained at $20{ }^{\circ} \mathrm{C}$ for $50 \mathrm{~min}$ and used as controls. After $50 \mathrm{~min}, 2 \mu \mathrm{L}$ of each reaction was diluted with $8 \mu \mathrm{L}$ seawater (35\%) in order to activate spermatozoa. Motility was assessed (phase contrast microscope at $400 \times$ magnification) and rated using an arbitrary scale, in which 0 represents $0 \%$, $1 \cong 1-25 \%, 2 \cong 26-50 \%, 3 \cong 51-75 \%, 4 \cong 76-90 \%$, and $5 \cong 91-100 \%$ motile spermatozoa [27].

\subsection{Experiment 6: development of SMGT protocol}

Semen was collected and spermatozoa were activated with seawater ( $1 \mu \mathrm{L}$ sperm and $49 \mu \mathrm{L}$ seawater) and their motility was immediately evaluated as previously described. Samples whose motility was below 50\% were discarded. Three washing solutions were tested to reduce activity of semen DNase (Table 1). An aliquot of $100 \mu \mathrm{L}$ of semen was mixed with $100 \mu \mathrm{L}$ of each washing solution and centrifuged at $1100 \times g$ for $3 \mathrm{~min}$ at $15^{\circ} \mathrm{C}$. Supernatants were carefully discarded without perturbing the pellets. Semen was mixed again with the same volume of each washing solution and centrifuged at $1100 \times g$ for another $3 \mathrm{~min}$ at $15{ }^{\circ} \mathrm{C}$. This procedure was repeated three times.

Two concentrations of pKeratin-GFP (10 and $50 \mathrm{ng} /$ $10^{6}$ sperm cells) were used to evaluate the uptake of exogenous DNA by washed spermatozoa. Spermatozoa motility was evaluated after $50 \mathrm{~min}$ incubation at room temperature $\left(20^{\circ} \mathrm{C}\right)$ as described previously. Semen 
Table 1

Composition of three washing solutions for washing fish spermatozoa

\begin{tabular}{lccc}
\hline Composition $(\mathrm{mM})$ & Solution $^{\mathrm{a}}$ & ${\text { Solution } \mathrm{II}^{\mathrm{b}}}$ & ${\text { Solution } \mathrm{III}^{\mathrm{c}}}^{\circ}$ \\
\hline Sucrose & 150 & - & - \\
$\mathrm{CaCl}_{2}$ & 1.7 & 2.7 & - \\
$\mathrm{MgSO}_{4}$ & 7 & - & - \\
$\mathrm{Glicina}$ & 86 & - & - \\
Trizma & 30 & - & 53.65 \\
$\mathrm{NaCl}$ & - & 70 & - \\
$\mathrm{KCl}$ & - & 1.5 & - \\
$\mathrm{MgCl}_{2}$ & - & 6.1 & - \\
$\mathrm{Glucose}_{\mathrm{NaHCO}}$ & - & 0.4 & 62.5 \\
$\mathrm{Citric}$ acid $\left(\mathrm{H}_{2} \mathrm{O}\right)$ & - & 25 & - \\
Na citrate $\left(2 \mathrm{H}_{2} \mathrm{O}\right)$ & - & - & 16.9 \\
EDTA & 25 & - & 34 \\
\end{tabular}

${ }^{\text {a }}$ Modified from Tvedt et al. [39].

b Modified from Dreanno et al. [40].

c Modified from Lavitrano et al. [24].

samples $(10 \mu \mathrm{L})$ without exogenous DNA were used as controls.

In order to separate sperm cells from non-incorporated exogenous DNA, reactions were incubated with $0.1 \mathrm{mg}$ DNase I for $30 \mathrm{~min}$, followed by washing twice with the same solutions as described before.

To confirm the presence of GFP gene in spermatozoa, genomic DNA was extracted using the phenol/ chloroform method [28]. The DNA extracted from each treatment was used as template for PCR reactions. A $336 \mathrm{bp}$ fragment of the GFP gene was amplified using the specific primers eGFP-For (5'-AGCTGACCCTGAAGTTCATCTG-3') and eGFP-Rev (5'-TGATATAGACGTTGTGGCTGTTG-3'). The PCR was carried out in a $12.5 \mu \mathrm{L}$ reaction volume containing $1.25 \mu \mathrm{L}$ of $10 \times$ PCR buffer, $0.2 \mu \mathrm{m}$ of each primer, $0.2 \mathrm{~mm}$ of each dNTP, $0.75 \mathrm{~mm}$ of $\mathrm{MgCl}_{2}, 0.5$ unit of platinum Taq DNA polymerase (Invitrogen), and $1 \mu \mathrm{L}$ of DNA. The reactions were incubated at $94{ }^{\circ} \mathrm{C}$ for $1 \mathrm{~min}$, followed by 28 cycles of $30 \mathrm{~s}$ at $94{ }^{\circ} \mathrm{C}, 1 \mathrm{~min}$ at $55^{\circ} \mathrm{C}, 1 \mathrm{~min}$ at $72{ }^{\circ} \mathrm{C}$, and a final elongation step of $5 \mathrm{~min}$ at $72{ }^{\circ} \mathrm{C}$. PCR products were separated on $1 \%$ agarose gel stained with ethidium bromide $(0.5 \mu \mathrm{g} / \mathrm{mL})$ and visualized by ultraviolet transillumination.

\subsection{Statistical analyses}

One-way ANOVA was used to evaluate the effects of DNA concentration on sperm motility, as well as the effects of various treatments used to develop the SMGT protocol. Differences were considered significant at $P<0.05$. Tukey HSD multiple range test comparisons was used when significant differences existed among treatments. Linear regression analysis was carried out between the concentration of commercial DNase $(\mathrm{U} / \mu \mathrm{L})$ and the remnant exogenous DNA, in order to calculate the concentration of endogenous DNase in the seminal plasma of Brazilian flounder. Data are presented as means \pm SEM. All analyses were conducted using software Statistica version 6.0 (Statsoft, Tulsa, OK, USA).

\section{Results}

\subsection{Experiment 1: Detection of DNase activity in seminal plasma}

The pKeratin-GFP transgene was completely digested when incubated with the seminal plasma
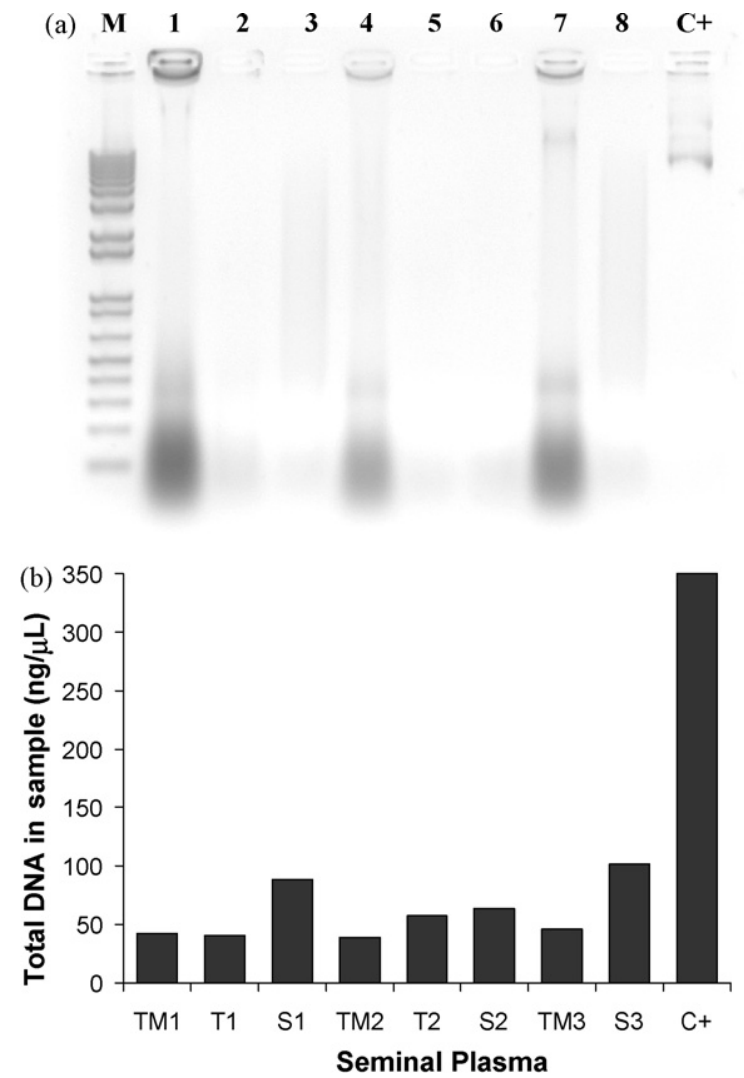

Fig. 1. Detection of DNase activity in flounder Paralichthys orbignyanus seminal plasma. (a) DNase activity analyzed by electrophoresis on $1 \%$ agarose gel. M, $1 \mathrm{~KB}$ plus DNA molecular marker; lanes 1, 2 and 3, seminal plasma from macerated testes $\left(\mathrm{TM}_{1}\right)$, testes semen $\left(\mathrm{T}_{1}\right)$ and ejaculated semen $\left(\mathrm{S}_{1}\right)$, respectively (individual 1$)$; lanes 4, 5 and 6, seminal plasma from macerated testes $\left(\mathrm{TM}_{2}\right)$, testes semen $\left(\mathrm{T}_{2}\right)$, and ejaculated semen $\left(\mathrm{S}_{2}\right)$, respectively (individual 2 ); lanes 7 and 8 , seminal plasma from macerated testes $\left(\mathrm{TM}_{3}\right)$, and ejaculated semen $\left(\mathrm{S}_{3}\right)$, respectively (individual 3). C+, pKeratin-GFP $(350 \mathrm{ng} / \mu \mathrm{L})$. (b) Concentration of remnant pKeratin-GFP $(\mathrm{ng} / \mu \mathrm{L})$ determined by fluorescence analysis using seminal plasma samples of various origins. 
of $P$. orbignyanus for $50 \mathrm{~min}$ at $20^{\circ} \mathrm{C}$ (Fig. 1a and b), suggesting the presence of DNase activity, independent of the origin of seminal plasma. However, there seemed to be a trend for reduced DNase activity of seminal plasma from ejaculated semen compared with seminal plasma obtained directly from the testes (Fig. 1b).

\subsection{Experiment 2: Determination of optimum incubation time and temperature of DNase activity}

In the experiment for determination of optimum incubation time, $350 \mathrm{ng}$ of DNA were utilized and degradation was observed for all times tested (Fig. 2a). Based on quantification through fluorescence analysis, DNase activity was apparent immediately after seminal plasma was added $(0 \mathrm{~min})$, where only $98 \mathrm{ng}$ of remaining DNA were detected, demonstrating that this enzyme acts very fast (Fig. 2b). From 15 to $60 \mathrm{~min}$,
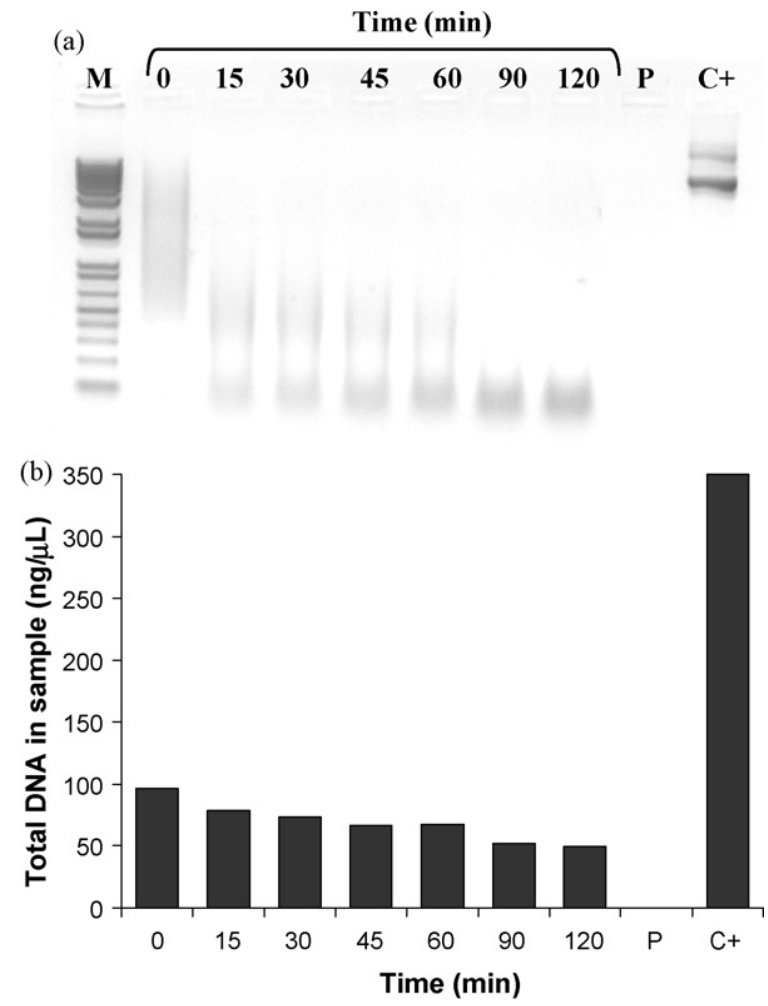

Fig. 2. Effect of time on DNase activity of seminal plasma of Brazilian flounder Paralichthys orbignyanus incubated at $20^{\circ} \mathrm{C}$. (a) DNase activity analyzed by electrophoresis on $1 \%$ agarose gel. M, $1 \mathrm{~KB}$ plus DNA molecular marker; seminal plasma was incubated with pKeratin-GFP for varying durations; $\mathrm{P}$, only seminal plasma; $\mathrm{C}+$, pKeratin-GFP (350 ng/ $\mu \mathrm{L})$. (b) Concentration of remnant pKeratinGFP (ng/ $\mu \mathrm{L})$ determined by fluorescence analysis after various incubation times.
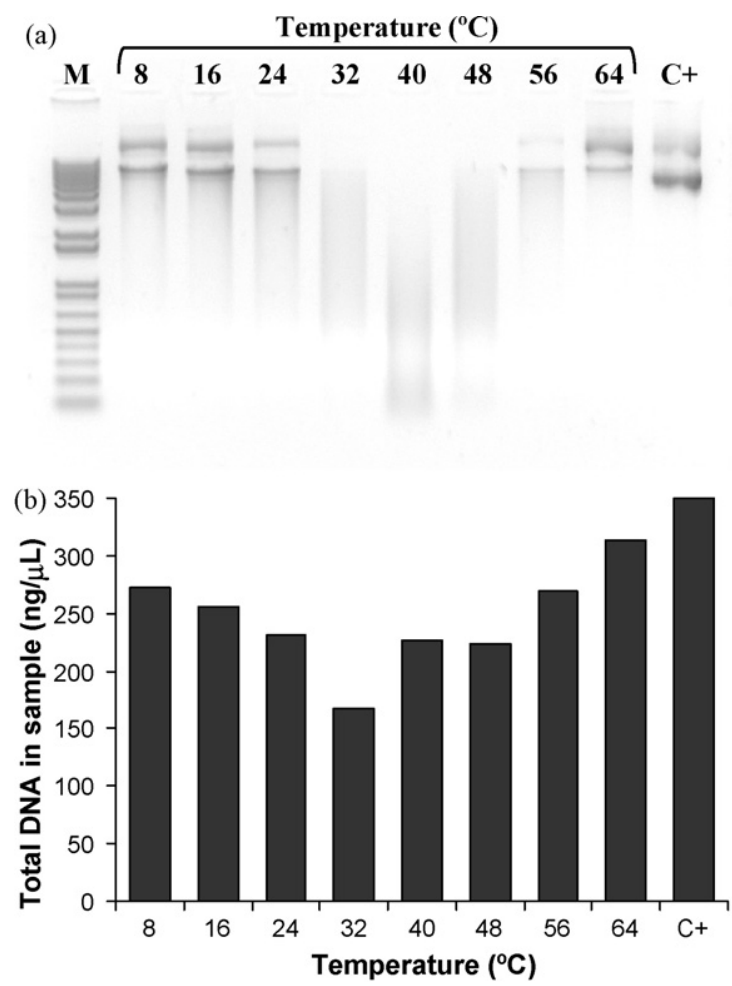

Fig. 3. Effect of temperature on DNase activity of seminal plasma of Brazilian flounder Paralichthys orbignyanus incubated for $30 \mathrm{~min}$. (a) DNase activity analyzed by electrophoresis on $1 \%$ agarose gel. M, $1 \mathrm{~KB}$ plus DNA molecular marker; seminal plasma was incubated with pKeratin-GFP at varying temperatures; C+, pKeratin-GFP (350 ng/ $\mu \mathrm{L})$. (b) Concentration of remnant pKeratin-GFP $(\mathrm{ng} / \mu \mathrm{L})$ determined by fluorescence analysis after various incubation temperatures.

DNA degradation did not substantially increase (78$67 \mathrm{ng}$ of remaining DNA detected, respectively). However, at 90 and $120 \mathrm{~min}$ of incubation, only approximately $50 \mathrm{ng}$ DNA remained.

Degradation of DNA occurred during incubations from 8 to $56{ }^{\circ} \mathrm{C}$ (Fig. 3a), but the optimal temperature for DNase activity was $32{ }^{\circ} \mathrm{C}$ (Fig. 3b). Conversely, at $64{ }^{\circ} \mathrm{C}$, DNase was not active (all exogenous DNA remained intact; Fig. 3a).

\subsection{Experiment 3: Determination of DNase concentration in seminal plasma}

The remaining amount of residual exogenous DNA decreased as the amount of seminal plasma was increased. The original concentration of DNA $(350 \mathrm{ng} / \mu \mathrm{L})$ was affected in a dose-dependent manner in all seminal plasma dilutions tested. However, the concentration of exogenous DNA was reduced approximately $50 \%$ when $1 \mu \mathrm{L}$ of undiluted seminal plasma 

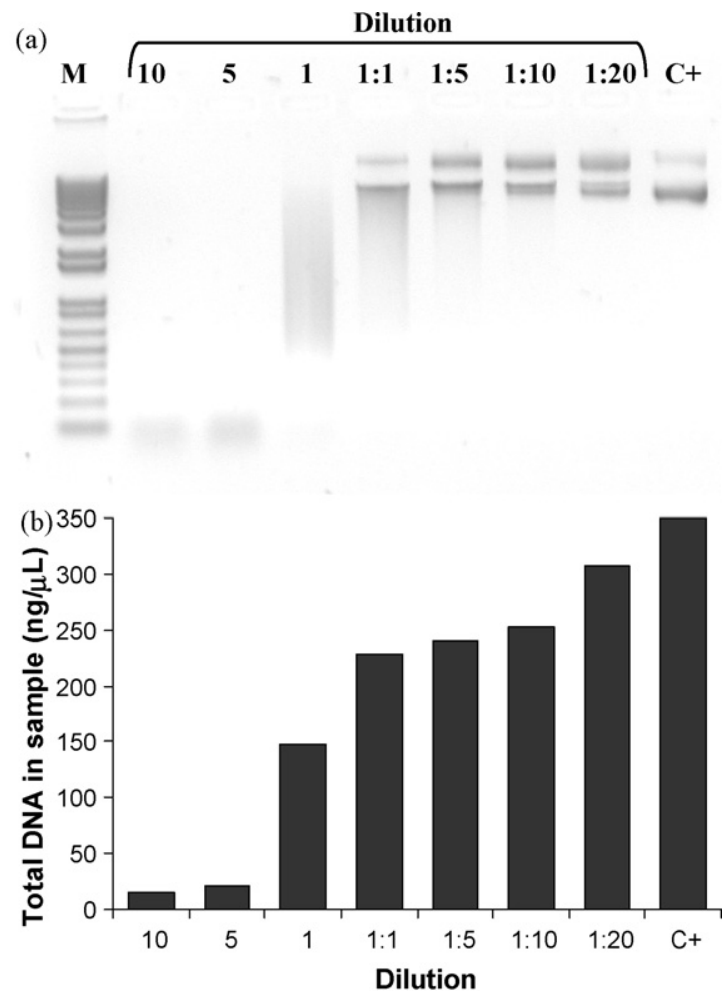

Fig. 4. Determination of concentration curve for DNase present in Brazilian flounder Paralichthys orbignyanus seminal plasma. (a) DNase activity analyzed by electrophoresis on $1 \%$ agarose gel. M, $1 \mathrm{~KB}$ plus DNA molecular marker; samples 10,5 and 1 are composed by 10,5 and $1 \mu \mathrm{L}$ of undiluted seminal plasma plus $1 \mu \mathrm{L}$ of pKeratinGFP (350 ng/ $\mu \mathrm{L})$, respectively; samples 1:1, 1:5, 1:10, and 1:20 were composed by $1 \mu \mathrm{L}$ of seminal plasma proportionally diluted with distilled water plus $1 \mu \mathrm{L}$ of pKeratin-GFP $(350 \mathrm{ng} / \mu \mathrm{L})$, respectively; $\mathrm{C}+$, pKeratin-GFP $(350 \mathrm{ng} / \mu \mathrm{L})$. (b) Concentration of remnant pKeratin-GFP $(\mathrm{ng} / \mu \mathrm{L})$ determined by fluorescence analysis following various dilutions of seminal plasma.

was incubated with DNA, whereas higher amounts of seminal plasma (5 and $10 \mu \mathrm{L}$ ) lead to complete DNA degradation (Fig. $4 a$ and b).

Regarding activity of commercial DNase I, $1 \mathrm{U} / \mu \mathrm{L}$ digested all exogenous DNA. However, exogenous DNA degradation decreased linearly from 0.1 to $0.01 \mathrm{U} / \mu \mathrm{L}$ DNase I, according to quantification of remnant DNA after electrophoresis and fluorescence analysis (Fig. 5a and b). The regression line which described this relationship was $y=-0.0005 x+0.1619$ $\left(P<0.0001\right.$; adjusted $\left.R^{2}=0.95\right)$, where $y$ is the number of DNase units and $x$ is the concentration of non-degraded exogenous DNA. Substituting values of remnant DNA incubated with decreasing concentrations of seminal plasma, the DNase concentration in Brazilian flounder seminal plasma was equal to $0.08 \pm 0.02 \mathrm{U} / \mu \mathrm{L}$.
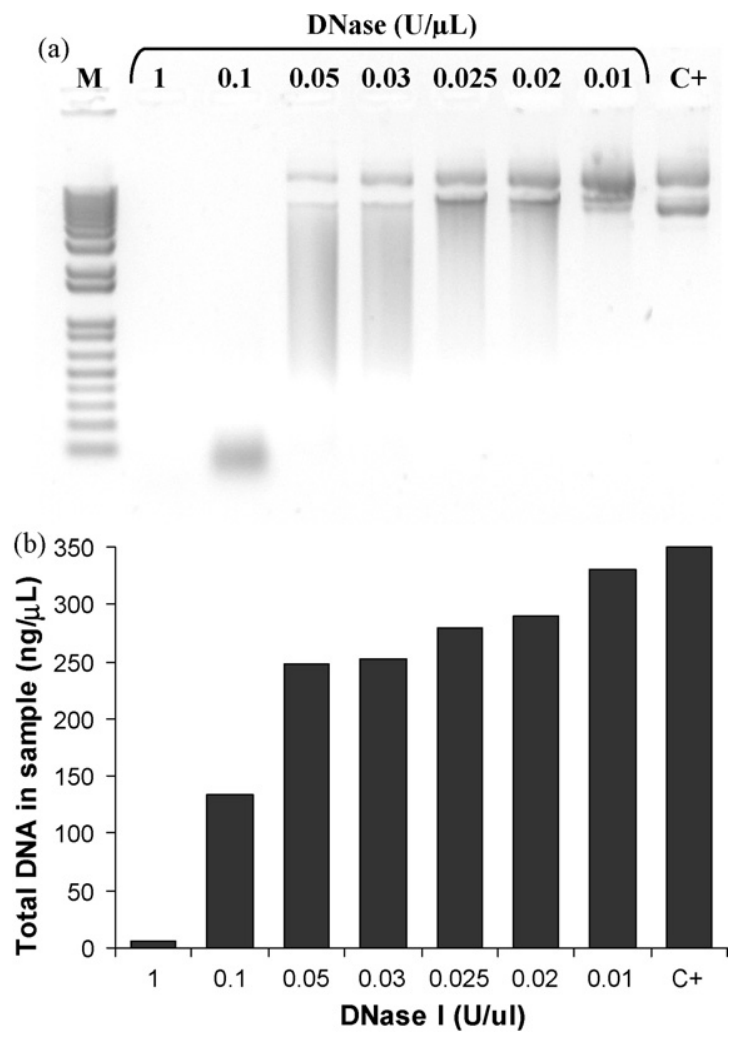

Fig. 5. Determination of concentration curve for commercial DNase I. (a) DNase activity analyzed by electrophoresis on $1 \%$ agarose gel. M, $1 \mathrm{~KB}$ plus DNA molecular marker; various quantities of commercial DNase $(\mathrm{U} / \mu \mathrm{L})$ were used in each reaction. C+, pKeratin-GFP $(350 \mathrm{ng} /$ $\mu \mathrm{L})$. (b) Concentration of remnant pKeratin-GFP $(\mathrm{ng} / \mu \mathrm{L})$ determined by fluorescence analysis using various quantities of commercial DNase.

\subsection{Experiment 4: Evaluation of EDTA on DNase activity}

As EDTA concentrations increased, DNase activity decreased. Degradation of exogenous DNA was reduced in EDTA concentrations of 20 and $30 \mathrm{mM}$; further increases in EDTA concentration (40, 105, and $215 \mathrm{mM}$ ) resulted in complete inhibition of DNase activity (Fig. 6a and b).

\subsection{Experiment 5: Evaluation of optimal concentration of exogenous DNA to use in SMGT}

The optimal exogenous DNA concentration to be used in SMGT was $50 \mathrm{ng} / 10^{6}$ spermatozoa, since sperm motility at this concentration $(2.5 \pm 0.28)$ was similar to the control $(2.6 \pm 0.08 ; P>0.05)$. Conversely, higher concentrations of exogenous DNA (100 ng/10 6 spermatozoa) significantly reduced motility of spermatozoa to 
(a)
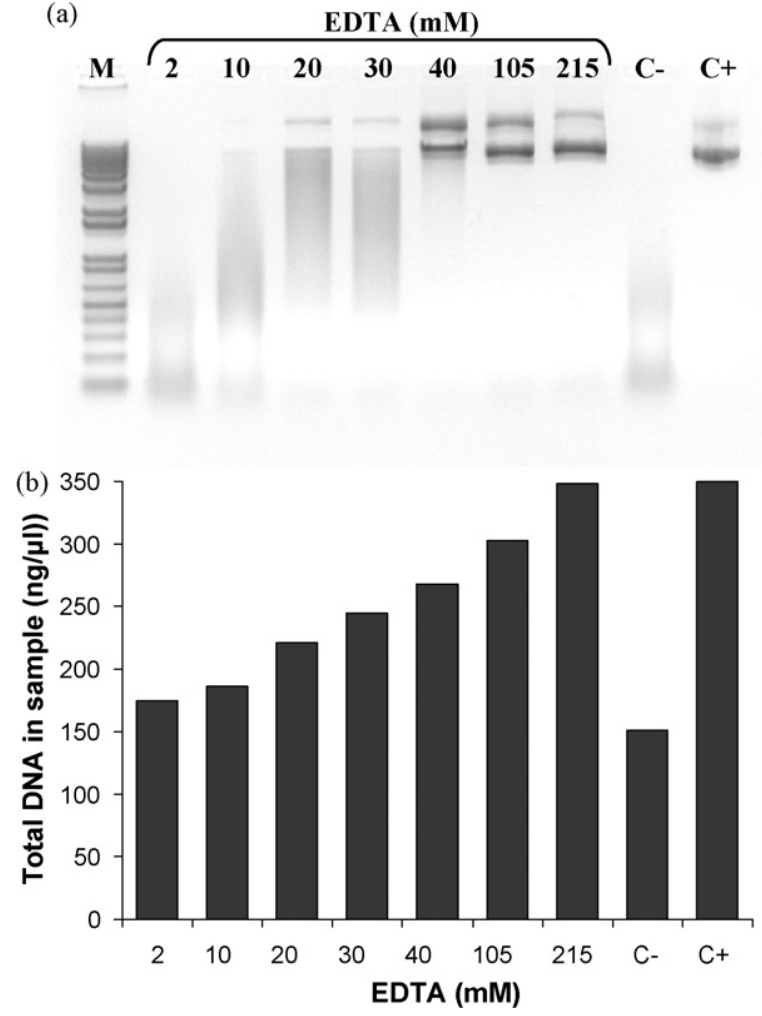

Fig. 6. Effect of EDTA concentration on DNase activity of seminal plasma from Brazilian flounder Paralichthys orbignyanus. (a) DNase activity analyzed by electrophoresis on $1 \%$ agarose gel. M, $1 \mathrm{~KB}$ plus DNA molecular marker; various concentrations of EDTA $(\mathrm{mM})$ were used in each reaction; $\mathrm{C}-$, seminal plasma + pKeratin-GFP without EDTA; ++ , pKeratin-GFP $(350 \mathrm{ng} / \mu \mathrm{L})$. (b) Concentration of remnant pKeratin-GFP $(\mathrm{ng} / \mu \mathrm{L})$ determined by fluorescence analysis after the seminal plasma had been treated with various concentrations of EDTA.

$1.0 \pm 0.05(P<0.05)$. The highest concentration tested $\left(500 \mathrm{ng} / 10^{6}\right.$ sperm cells) was lethal for spermatozoa, since motile cells were not observed.

\subsection{Experiment 6: Development of SMGT protocol}

When spermatozoa were incubated with $10 \mathrm{ng} / 10^{6}$ cells, there was no difference $(P>0.05)$ in sperm motility, independent of the washing solution used to eliminate the DNase activity. In the control sample, spermatozoa motility was $2.3 \pm 0.3$. For Solutions I, II and III sperm motility was $2.5 \pm 0.28,2.3 \pm 0.33$, and $1.8 \pm 0.16$, respectively. However, when spermatozoa were incubated with $50 \mathrm{ng} / 10^{6}$ cells, there was better motility $(P<0.05)$ in the treatments with solutions I $(2.5 \pm 0.28)$ and II $(1.5 \pm 0.28)$, whereas motility was poorest with solution III $(1.06 \pm 0.06$; $P<0.05)$.

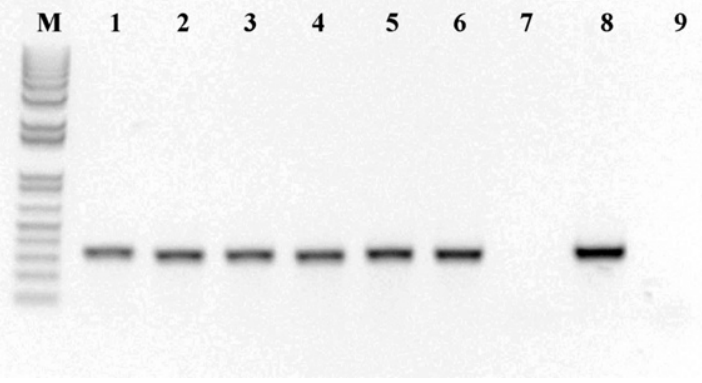

Fig. 7. Detection of pKeratin-GFP in spermatozoa of Brazilian flounder Paralichthys orbignyanus through PCR. M, $1 \mathrm{~KB}$ plus DNA molecular marker; lanes 1 and 2, sperm washed with solution I and incubated with 10 and $50 \mathrm{ng} / 10^{6}$ cells of exogenous DNA, respectively; lanes 3 and 4, sperm washed with solution II and incubated with 10 and $50 \mathrm{ng} / 10^{6}$ cells of exogenous DNA, respectively; lanes 5 and 6 , sperm washed with solution III and incubated with 10 and $50 \mathrm{ng} / 10^{6}$ cells of exogenous DNA, respectively; lane 7, fresh sperm (negative control); lane 8, pKeratin-GFP as a template (positive control); lane 9, no template added.

Uptake of exogenous DNA by Brazilian flounder spermatozoa was confirmed through PCR analyses, since the GFP gene was amplified in all treatments. All washing solutions, as well as the various concentrations of exogenous DNA (10 and $50 \mathrm{ng} / 10^{6}$ cells) used to develop the SMGT protocol allowed pKeratin-GFP to be internalized by spermatozoa (Fig. 7).

\section{Discussion}

In the present study, it was evident that the seminal plasma of Brazilian flounder contained strong DNase activity. To our knowledge, this is the first description of DNase activity in fish semen. However, DNase activity has been associated with the presence of seminal plasma in mammals [23,29,30] and chicken [31]. The epididymis is a source of mature spermatozoa free of seminal plasma in the mouse [23], accounting for the success of SMGT in rodents when this source of sperm was used. Conversely, in the present study, DNase activity in seminal plasma was present in all sources of semen tested: ejaculated semen, semen from the lumen of the testes, and semen from macerated testes. The presence of DNase in seminal plasma is likely the cause of failure of other attempts to produce transgenic fish using SMGT. According to Carballada and Esponda [23], this enzyme is the main source of inhibition of DNA uptake by mammalian spermatozoa.

It was noteworthy that DNase activity was completely inhibited by $40 \mathrm{mM}$ EDTA. Similarly, $50 \mathrm{mM}$ EDTA diminished DNase activity in chicken and mouse semen $[23,31]$. This organic chelator eliminates free 
divalent cations $\left(\mathrm{Ca}^{2+}\right.$ and $\left.\mathrm{Mg}^{2+}\right)$ in the medium. Therefore, we inferred that the DNAse activity found in Brazilian flounder seminal plasma was DNase I, since this class of enzyme depends on divalent cations to exert its activity. Previously, Yamamoto [32] reported the activity of DNase II in salmon $O$. tshawytscha seminal plasma from testes and Nechaevsky and Ivanov [33] found the same enzyme in loach Misgurnus fossilis spermatozoa. However, DNase II is only active at acid $\mathrm{pH}$ and in the absence of bivalent cations. Therefore, this enzyme does not appear to play an important role in the interaction between sperm and exogenous DNA.

The amount of DNA that should be employed in SMGT is another limiting factor in transgenic animal production. Although high concentrations of exogenous DNA increased the possibility of DNA uptake by spermatozoa, it also decreased sperm cell motility, viability and fertilizing capacity [7,34,35]. Maione et al. [36] also observed that high DNA concentrations $\left(100-500 \mathrm{ng} / 10^{6}\right.$ cells) induced strong nuclease activity in sperm cells, yielding not only cleavage of the foreign DNA, but also degradation of sperm chromosomal DNA. Thus, a process resembling apoptosis is triggered in spermatozoa when increased concentrations of exogenous DNA are used for SMGT. In the present study, similar processes were detected in $P$. orbignyanus semen. Reduction of sperm motility was observed when pKeratin-GFP (100 ng/10 6 cells) was used. Furthermore, motile spermatozoa were not observed at higher DNA concentrations, indicating that spermatozoa could be undergoing apoptosis as described by Maione et al. [36] for spermatozoa in mice. Only the lowest DNA concentration evaluated did not affect spermatozoa motility. According to Rurangwa et al. [37], motility is directly related to sperm fertilizing capacity and is one of the primary measures of semen quality in fish. Therefore, the amount of DNA used for SMGT in fish should not exceed $50 \mathrm{ng} / 10^{6}$ cells.

Three points must be considered for the development of a SMGT protocol for fish: (i) seminal plasma DNase activity must be eliminated; (ii) a suitable washing solution must be used to maintain sperm quality; and (iii) DNA concentration should be low enough to maintain sperm motility, but simultaneously high enough to allow DNA uptake by spermatozoa. The outcome of the present study provided suitable information for the development of a SMGT protocol for Brazilian flounder. First, DNase activity was decreased by addition of EDTA in all washing solutions. Moreover, this was augmented by washing semen before incubation with exogenous DNA. Second, all tested solutions were efficient in preserving spermatozoa motility, particularly when sperm cells were incubated with $10 \mathrm{ng}$ DNA $/ 10^{6}$ cells. However, when spermatozoa were incubated with $50 \mathrm{ng} / 10^{6}$ cells, motility was higher for solutions I and II, probably due to the presence of $\mathrm{CaCl}_{2}$ in these washing solutions. Alavi and Cosson [38] suggested that motility of spermatozoa of some marine fish is regulated by osmotic pressure as well as by the presence of the ion $\mathrm{Ca}^{2+}$, which sustains sperm motility at high osmotic pressure. Third, the DNA concentrations $\left(10-50 \mathrm{ng} / 10^{6}\right.$ cells) used for development of the SMGT protocol were adequate because they allowed spontaneous DNA uptake by spermatozoa.

In summary, we inferred that DNA uptake by fish spermatozoa was strongly regulated by the presence of DNase in seminal plasma. However, fish spermatozoa took up and incorporated exogenous DNA after DNase activity was reduced. Moreover, the proposed protocol provides opportunities for pursuing the production of transgenic fish through SMGT.

\section{Acknowledgments}

The authors thank Maíra Proietti for revision of the manuscript. CFC Lanes is supported by the Brazilian $\mathrm{CNPq}$ and Programa de Pós-graduação em Aqüicultura (PPGAq-FURG), and LA Sampaio is a research fellow of the Brazilian CNPq (Process 301673/2006-3).

\section{References}

[1] Ozato K, Kondoh H, Inohara H, Iwamatsu T, Wakamatsu Y, Okada TS. Production of transgenic fish: introduction and expression of chicken $\delta$-crystallin gene in medaka embryos. Cell Differ 1986;19:237-44.

[2] Inoue K, Yamashita S, Hata J-I, Kabeno S, Asada S, Nagahisa E Electroporation as a new technique for producing transgenic fish Cell Differ Dev 1990;29:123-8.

[3] Lu JK, Fu BH, Wu JL, Chen TT. Production of transgenic silver sea bream (Sparus sarba) by different gene transfer methods. Mar Biotechnol 2002;4:328-37.

[4] Lin S, Gaiano N, Culp P, Burns JC, Friedmann T, Yee JK. Integration and germ-line transmission of a pseudotyped retroviral vector in zebrafish. Science 1994;265:666-9.

[5] Yazawa R, Hirono I, Yamamoto E, Aoki T. Gene transfer for Japanese flounder fertilized eggs by particle gun bombardment Fisheries Sci 2005;71:869-74

[6] Hostetler HA, Peck SL, Muir WM. High efficiency production of germ-line transgenic Japanese medaka (Oryzias latipes) by electroporation with direct current-shifted radio frequency pulses. Transgenic Res 2003;12:413-24.

[7] Lavitrano M, Camaioni A, Fazio VM, Dolci S, Farace MG, Spadafora C. Sperm cells as vectors for introducing foreign DNA into eggs - genetic transformation of mice. Cell 1989;57: 71723. 
[8] Sperandio S, Lulli V, Bacci ML, Forni M, Maione B, Spadafora C, Lavitrano ML. Sperm-mediated DNA transfer in bovine and swine species. Anim Biotechnol 1996;7:59-77.

[9] Hoelker M, Mekchay S, Schneider H, Bracket B, Tesfaye D, Jennen D, Tholen E, Gilles M, Rings F, Griese J. Quantification of DNA binding, uptake, transmission and expression in bovine sperm mediated gene transfer by RT-PCR: effect of transfection reagent and DNA architecture. Theriogenology 2007;67:1097107.

[10] Nakanishi A, Iritani A. Gene transfer in the chicken by spermmediated methods. Mol Reprod Dev 1993;36:258-61.

[11] Habrova V, Takac M, Navratil J, Macha J, Ceskova N, Jonak J. Association of Rous sarcoma virus DNA with Xenopus laevis spermatozoa and its transfer to ova through fertilization. Mol Reprod Dev 1996;44:32-42.

[12] Arezzo F. Sea-urchin sperm as a vector of foreign genetic information. Cell Biol Int Rep 1989;13:391-404.

[13] Atkinson PW, Hines ER, Beaton S, Matthaei KI, Reed KC, Bradley MP. Association of exogenous DNA with cattle and insect spermatozoa in vitro. Mol Reprod Dev 1991;29:1-5.

[14] Muller F, Ivies Z, Erdelyi F, Papp T, Varadi L, Horvath L, Maclean $\mathrm{N}$. Introducing foreign genes into fish eggs with electroporated sperm as a carrier. Mol Mar Biol Biotechnol 1992;1:276-81.

[15] Patil JG, Khoo HW. Nuclear internalization of foreign DNA by zebrafish spermatozoa and its enhancement by electroporation. J Exp Zool 1996;274:121-9.

[16] Sin FYT, Walker SP, Sin IL, Symonds JE, Mukherjee UK, Khoo JGI. Electroporation of salmon sperm for gene transfer: eficiency, realiability, and fate of transgene. Mol Reprod Dev 2000;56:285-8.

[17] Zhong JY, Wabg YP, Zhu ZY. Introduction of the human lactoferrin gene into grass carp (Ctenopharyngodon idellus) to increase resistance against GCH virus. Aquaculture 2002;214: 93-101.

[18] Chourrout D, Perrot E. No transgenic rainbow trout produced with sperm incubated with sperm linear DNA. Mol Mar Biol Biotechnol 1992;1:282-5.

[19] Sin FYT, Bartley AL, Walker SP, Sin IL, Symonds JE, Hawke L, Hopkins CL. Gene transfer in chinook salmon (Oncorhynchus tshawytscha) by electroporating sperm in the presence of pRSVlacZ DNA. Aquaculture 1993;117:57-69.

[20] Liu XY, Zohar Y, Knibb W. Association of foreign DNA with sperm of gilthead seabream, Sparus aurata, after sonification, freezing and dimethyl sulfoxide treatments. Mar Biotechnol 1999; 1:175-83.

[21] Khoo HW, Ang LH, Lim HB, Wong KY. Sperm cells as vectors for introducing foreign DNA into zebrafish. Aquaculture 1992;10:1-19.

[22] Zani M, Lavitrano M, French D, Lulli V, Maione B, Sperandio S, Spadafora C. The mechanism of binding of exogenous DNA to sperm cells - factors controlling the DNA uptake. Exp Cell Res 1995;217:57-64.

[23] Carballada R, Esponda P. Regulation of foreign DNA uptake by mouse spermatozoa. Exp Cell Res 2001;262:104-13.
[24] Lavitrano M, Forni M, Bacci ML, Di Stefano C, Varzi V, Wang $\mathrm{H}$, Seren E. Sperm mediated gene transfer in pig: selection of donor boars and optimization of DNA uptake. Mol Reprod Dev 2003;64:284-91.

[25] Lavitrano M, Busnelli M, Cerrito MG, Giovannoni R, Manzini S, Vargiolu A. Sperm-mediated gene transfer. Reprod Fertil Dev 2006;18:19-23.

[26] Radonic M, Müller MI, López AV, Bambill GA, Spinedi M, Boccanfuso JJ. Improvement in flounder Paralichthys orbignyanus controlled spawning in Argentina. Cienc Mar 2007;33:18796.

[27] Borges A, Siqueira DR, Jurinitz DF, Zanini R, Amaral F, Grillo ML, Oberst ER, Wassermann GF. Biochemical composition of seminal plasma and annual variations in semen characteristics of jundiá Rhamdia quelen (Quoy and Gaimard, Pimelodidae). Fish Physiol Biochem 2005;31:45-53.

[28] Sambrook J, Fritsch EF, Maniatis T. Molecular cloning: a laboratory manual, 2nd ed., Cold Spring Harbor, New York: Cold Spring Harbor Laboratory Press; 1989.

[29] Tanigawa Y, Yoshihara K, Koide SS. Endonuclease activity in bull semen, testis and accessory sex organs. Biol Reprod 1975;12:464-70.

[30] Takeshita H, Yasuda T, Nadano D, Tenjo E, Sawazaki K, Iida R, Kishi K. Detection of deoxyribonucleases I and II (DNases I and II) activities in reproductive organs of male rabbits. Int $\mathbf{J}$ Biochem 1994;26:1025-31.

[31] Sato F, Soh T, Hattori M-A, Fujihara N. Evaluation of deoxyribonuclease activity in seminal plasma of ejaculated chicken semen. Asian J Androl 2003;5:213-6.

[32] Yamamoto M. Purification and some properties of an acid deoxyribonuclease from testes of chinook salmon Oncorhynchus tshawytscha. Biochim Biophys Acta 1971;228:95-104.

[33] Nechaevsky YV, Ivanov VA. DNase II in spermatozoa of the loach Misgurnus fossilis L.. Biochemistry 1999;64:488-93.

[34] Sasaki S, Kojima Y, Kubota H, Tatsura H, Hayashi Y, Kohri K. Effects of the gene transfer into sperm mediated by liposomes on sperm motility and fertilization in vitro. Hinyokika Kiyo 2000;29:6-15.

[35] Anzar M, Buhr MM. Spontaneous uptake of exogenous DNA by bull spermatozoa. Theriogenology 2006;65:683-90.

[36] Maione B, Pittogi C, Achene L, Lorenzini R, Spadafora C. Activation of endogenous nucleases in mature sperm cells upon interaction with exogenous DNA. DNA Cell Biol 1997;16:1087-97.

[37] Rurangwa E, Kime DE, Ollevier F, Nash JP. The measurement of sperm motility and factors affecting sperm quality in cultured fish. Aquaculture 2004;234:1-28.

[38] Alavi SM, Cosson J. Sperm motility in fishes. (II). Effects of ions and osmolality: a review. Cell Biol Int 2006;30:1-14.

[39] Tvedt HB, Benfey TJ, Martin-Robichaud DJ, Power J. The relationship between sperm density, spermatocrit, sperm motility and fertilization success in Atlantic halibut, Hippoglossus hippoglossus. Aquaculture 2001;194:191-200.

[40] Dreanno C, Suquet M, Desbruyères E, Cosson J, Delliou HL, Billard R. Effect of urine on semen quality in turbot Psetta maxima. Aquaculture 1998;169:247-62. 